\title{
Modren Patterns of Residential Units and their Impact in Deformation of the Morphoogy of the Rural Settlements in Iraq
}

\author{
Miged Abbas Abd Al-Naggar Abass Ismael Ibrahim Mahmood Chabuk
}

Department of Architecture, College of Engineering, University of Babylon, Babylon, Iraq

mijedd@yahoo.com mabass70@yahoo.com mahmoodchabuk@yahoo.com

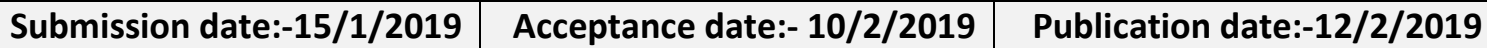

\begin{abstract}
:
Research work on finding out the role of the existence of houses of new pattern in changing and deforming the morphology of rural statement in the middle region in Iraq. The first stage was to explore the charachteristics of traditional house in Iraqi rural statement and find out the factors that made these charachteristics to make easy make a comparison of new houses with new pattern. A finding result shows up that deformation may occurs in architectural forms in case of the absence of specific beauty elements. To make sure of that, verbal and written quastionaires were done for selected rural statments houses owners and architecture experts who indicated the presence of big deformation in samples of houses tissue that include both traditional and new pattern together in rural statements.
\end{abstract}

Keywords: Morphology, Bulding patterns, Rural statement, Deformation. 


\section{الاتماط الحديثة للوحات السكنية وأثرها في تثويه مورفولوجيا المستوطنات الريفية في العراق}

محمود عامر جابك

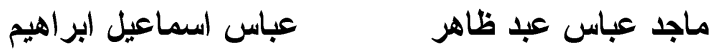

قسم هندسة العدارة، كلية الهندسة، جامعة بابل، بابل، العرلق

mahmoodchabuk@yahoo.com mabass70@yahoo.com $\underline{\text { mijedd@yahoo.com }}$

الخلاصة

يعمل البحث على ايجاد العلاقة والاثر الذي يثركه استحداث و انثاء الوحدات السكنية الحديثة النمط (المواد الانثائية و اللغــة

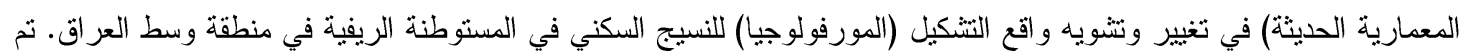
ابتداءا استعر اض خصائص نمط التتكيل للوحدة السكنية في الريف العر اقي والمتو ارث من الماضي، وكذلك معرفة العناصر التـي في فئي

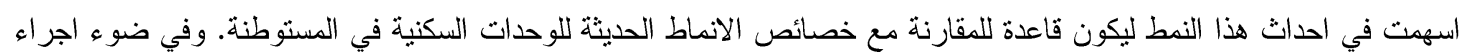

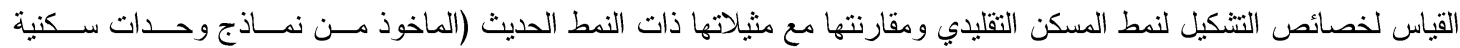

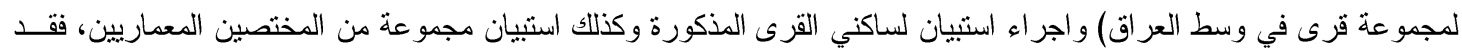

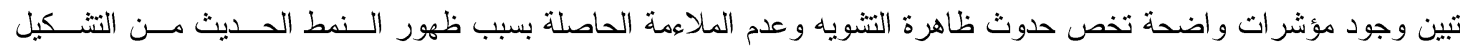

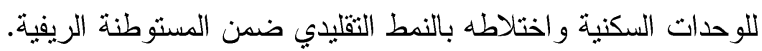
الكلمات الداله: المُورْفُولُوجيّا، انماط البناء، المستوطنة الريفية، التتوه.

1-المقدمة:

تعد مر اكز الاستيطان الريفي المظهر الاول للاستعمال البشري على سطح الارض، لقد انتشرت في الآونة الاخيرة ظــاهرة

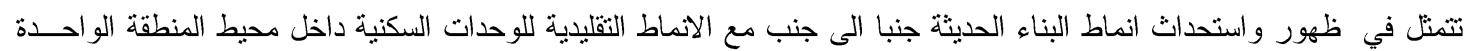

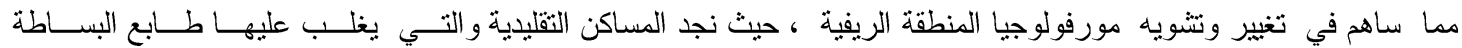

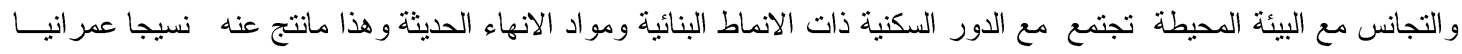
مشو ها وغير متجانس مما اثرسلبا في محتوى وجمال و عفوية مظهر المستوطنة الريفية و أفقد القرية طابعها المعهــاري المميـز

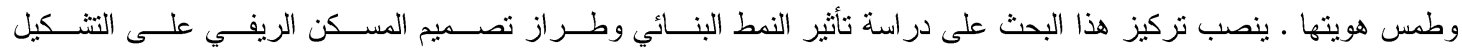
المورفولوجي للمنطقة الريفية، والأثز الذي بتركه تعدد واختلاف انماط البناء للاور السكنية في انتاج مظاهر عمر انية جديدة ساهت في تغيير مورفولوجيا المنطقة لريفية.

شكل غياب الإطار النظري المتكامل الذي يدرس مظاهر التشوه الحاصل في مورفولوجيا المستوطنة الريفية فـــ منــاطق

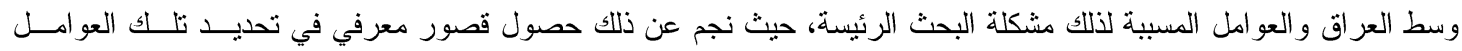

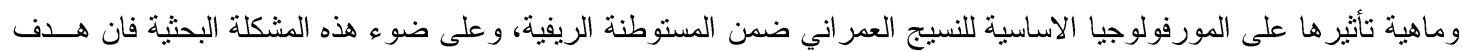
البحث يكمن في التوصل الى أنموذج نظري متكامل يحدد الاتي:

أ- اهم عو امل التغيير الذي تتاثر بموجبه مورفولوجيا المنطقة الريفية وذلك بدراسة الجوانب المتعلقة بها. ب- إثر ظاهرة النمو العمر اني وتأثثره في تغيير مورفولوجيا المستوطنة الريفية. ت-النتكيل المورفولوجي للمستوطنة الريفية المعاصرة عن طريق دراسة انماط الدور السكنية فيها ضمن نماذج مستوطنات ريفية

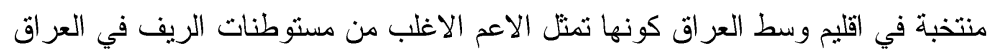

وقد نصت فرضية البحث على ان الاختلاف الحاصل بين نمطي الوحدات السكنية (التقليدي و الحديث) وتعددها واجتماعهـــا معا داخل محيط المنطقة الواحدة ضمن المستوطنة الريفية بساهم في تغيير ونتويه مورفولوجيا المنطقة الريفية، وهذا ما ينتج نسيجا 
عمر انيا مشو ها وغير متجانس قد أثز في مظهر ومشهد القرية الريفية، وأفقدها الطابع المعماري المميز لنسيجها العمر اني ومن ثـم هم غياب وطمس هويتها.

اعتمد البحث المنهج الوصفي التحليلي في ضوء جمع ودر اسة ومن ثم تحليل المعلومات النظرية والتي تخص الاطار العسام

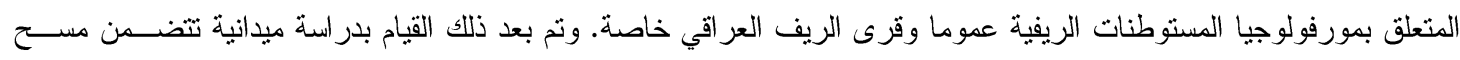
ووصف المورفولوجيا المستحدثة للوحدات السكنية في مجموعة منتخبة من قرى تقع في وسط العراق، وقد نم اعتماد اسلوب اجر اء

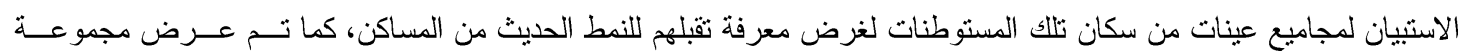
منتخبة من مشاهد لوحدات السكنية في تلك القرى النمطين على خبر اء معماريين التقيبم تلك المشاهد وبيان التثوه ان وجد.

\section{2- المورفولوجيا (Morphology)}

2-2-2 المورفولوجيا لغة واصطلاحاً:

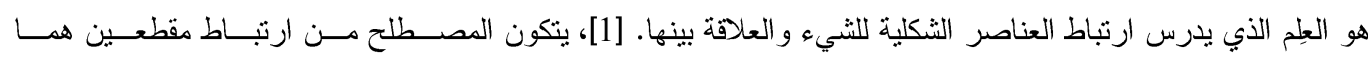

(Morph+logy)

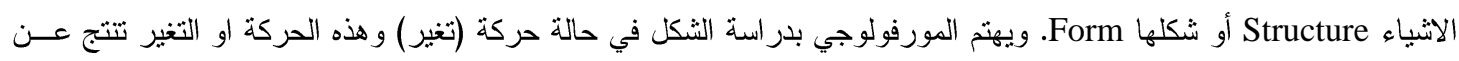
طريق مؤثرات موضعية غير مدركة ومؤثرات البيئة الطبيعية والثقافية وغير ها والتي يندرج الانسان ضمن مكوناتها. [2]

\section{2-2 المورفولوجيا في العمارة (Morphology in Architecture):}

المورفولوجيا في العمارة تهتم بدر اسة الأشكال المعمارية والتي تتجسد في العمل المعماري المنفرد على شكل تمفصل شكلي [3]، إذْ إن خصائص الثكل تحدد بو اسطة حدوده، مما يعني ان الحد هو محدد للشيء وخصائصه [4]. اما في التصميم الحضــري فئي

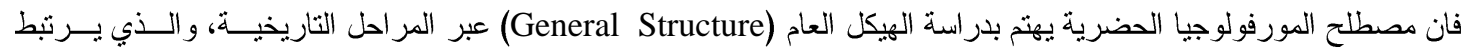

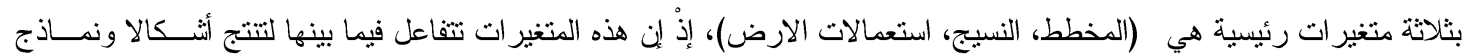

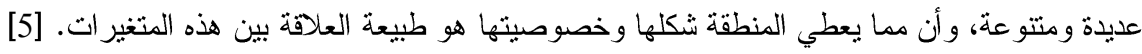
2-3 تصنيف الدراسات المورفولوجية: هنالك ثلاثة أصناف رئيسية متكاملة ومتداخلة لدراسة وتحليل التوجهات المورفولوجية

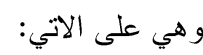
أ-التوجه التاريخي Historical Approach: هذا التوجه مبني على أساس دراسـة مر احل النمو التاريخي الذي تبرز من بينه أهم العناصر المميزة للنسيج العمر اني.

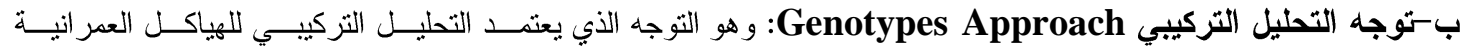

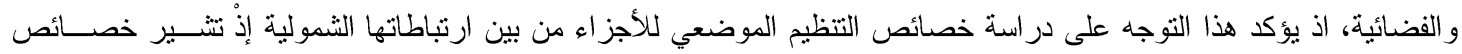

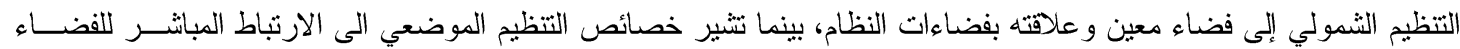

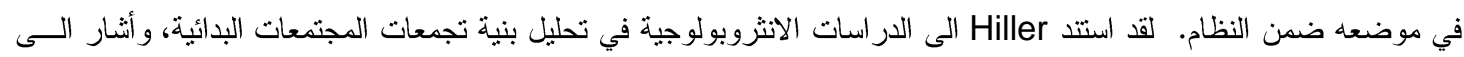

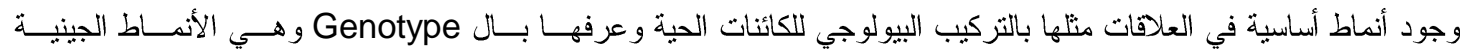

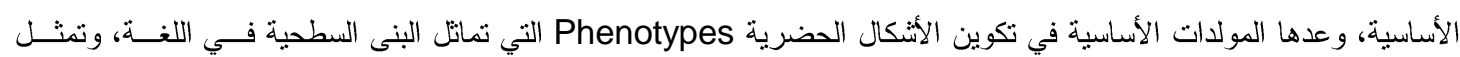

الأشكال الحضرية الظاهرة. ت-توجه تحليل الشكل الظاهر Phenotypes Approach: يهنم هذا التوجه بتحليل المخططات اعتمــاداً علـى الأثــكال الظاهرة، ويتضمن هذا التوجه در اسة المتغير ات الفيزيائية وكيفية تشكلها مورفولوجيا.

(Rural Settlements):المستوطنات الريفية

هي مجتمعات ثلبلة الكثافة السكانية توجد بعيدة عن المر اكز الحضرية المكنظة بالسكان، ويعنمد تعريف المستوطنة الريفية على البلد نفسه، فتعرف في بعض البلدان بأنها أية مستوطنة تقع ضمن المناطق التي تعرف على أنها ريفية من قبل الدولة، وعادة 
فإن المستوطنات الريفية تكون مرتبطة بفعالية الزراعة أما في العصر الحديث فقد نم ظهور وتطور أنواع أخرى من المجتمعات الريفية. أن المستوطنات الريفية تكون على اشكال مختلفة منها القرى Villages وهي مستوطنات بشرية تكون بشكل تجمعات

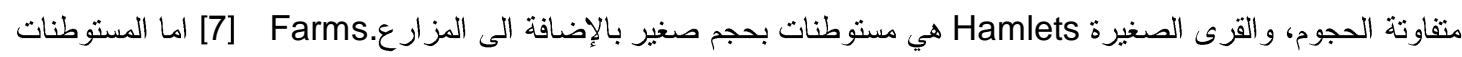
الريفية في العراق فهي عبارة عن تجمعات سكنية لعو ائل نرجع في نسبها لاصول عشائرية مختلفة موزعة في انحاء مختلفة من العر اق. و عندما استقرت هذه العو ائل بدأت علاقتها تقوى ضمن ضوابط اجتماعية تضمن لهم العيش في سلام ومودة [8]. ان معظم المسنوطنات الريفية في وسط العراق تتركزعلى امتداد ضفاف نهري دجلة و الفرات، وان واقع هذه المستوطنات من الناحية

التخطيطية يتمثل بالآتي: [9

$$
\text { أ- أغلبها لبس لها تخطيط مُسبق، حيث بُنبت مساكنها بثكل شبه عشو ائي. }
$$

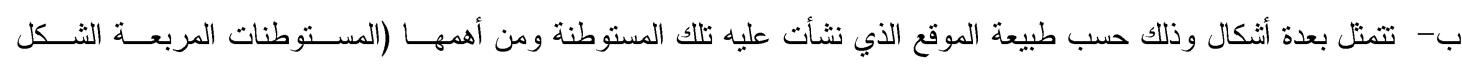
و المسنوطنات الثريطية).

ت-إن مُعظم طرق هذه المستوطنات ومسالكها مُتعرجة، غير مستقيمة وضيقة تستخدم من قبل السابلة وماشيتهم، صورة (1). ث-تفتقر الى البنى التحتية وأبنية الخدمات التي تحتاجها بمختلف أنو اعها من مدرسة، مركز شرطة، سوق.

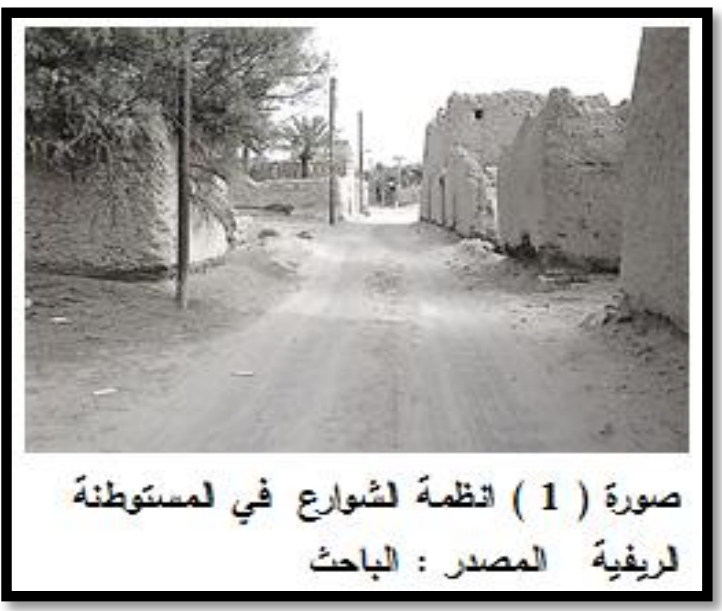

3-1- عناصر مورفولوجية المستوطنة الريفية [10]

يعد التركيب المورفولوجي للمستوطنة الريفيــة نتاجــاً

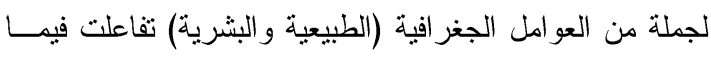
بينها لتحديد الموضع المناسب ورسم نمط ابنيتها عبر مراحلـل

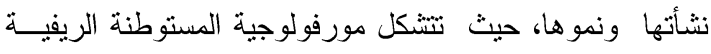
من تأثيرمجموعة عناصر متفاعلة تنكل البنية والمظهر العسام

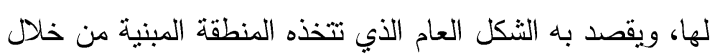

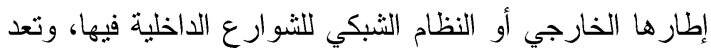
در استها أهم عنصر مورفولوجي يتضمن مجموعة محاور تعمل

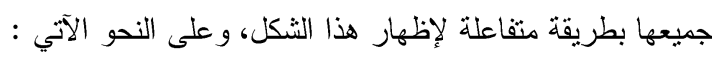

أ- أنظمة الثوارع: وتتمل المسالك التي تستخدم لمرور الأثخاص و السيار ات، و التي تثباين من حيث الامتداد و السـعة و التعـرج

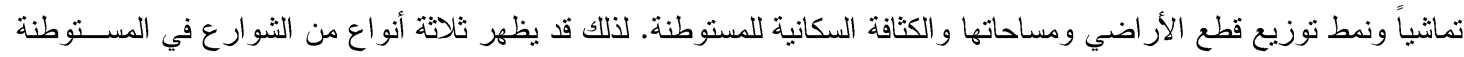

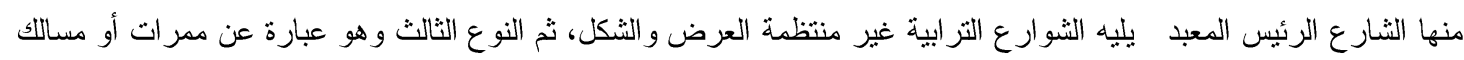
ضيقة ومتعرجة تمثل بين الوحدات السكنية.

ب- نمط قطع الأراضي : هو النسق أو الترتيب الذي تتخذه قطع الأراضي المشيدة للاستعمالات المختلفة، و التي في مجملها تثكل

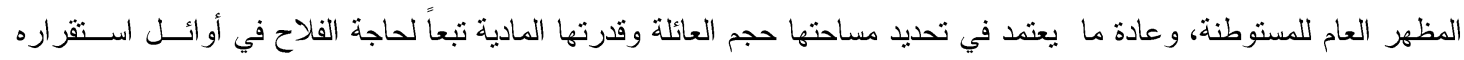

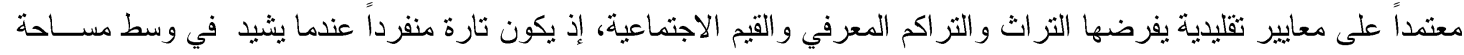

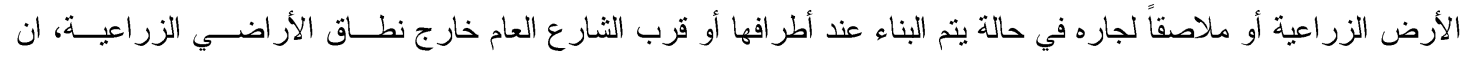

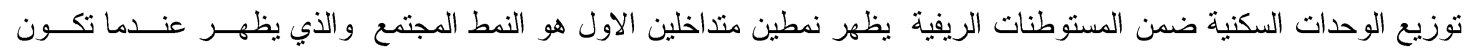

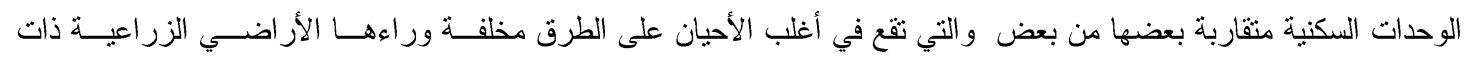

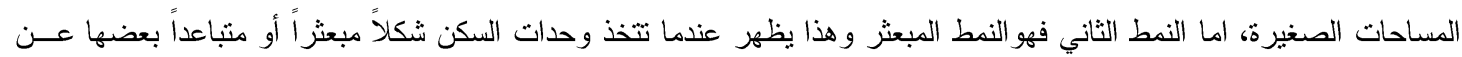

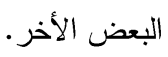

ث- أنماط الأبنية : بعد المسكن الريفي ( المكون الغالب في المستوطنة الريفية ) وحدة ذات إطار مادي يعكس الواقــع الــوظيفي

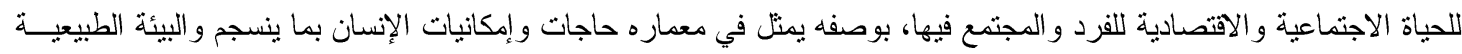
من حيث التصميم وأسلوب البناء الذي يعبر في أصالته عن التراكم الحضاري السائد في المنطقة فضلاً عن أن هذا الــنمط الســكني 
يحمل في طياته فعاليات انتاجية متممة للوظائف الزر اعية وتربية الحيوانات من خلال ما يحتويه المسكن مــن الفضـــاءات المغلقـــة و المفتوحة تعكس خصوصية الحياة الريفية وطييعة الأعمال التي يمارس اهلها، وقلما نجد مسكنين منطابقين في مخططهما الــداخلي، و هذا لا يعني عدم وجود تقارب في مكونات تصاميمها التي تشكل في مجموع عناصر ها الأساسية المسكن الريفي.

ث- استعمالات الأرض في المستوطنة: بما أن المستوطنة لم تخضع إلى أي تخطيط في هيكلها التصميمي يحدد نـــوع الاســتعمال

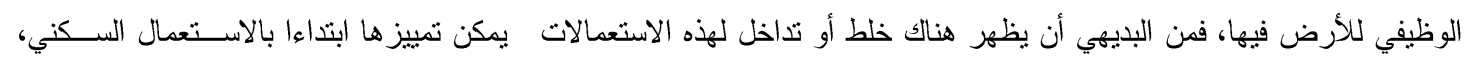

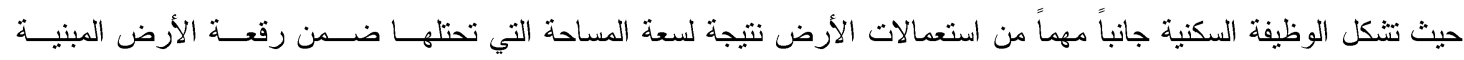

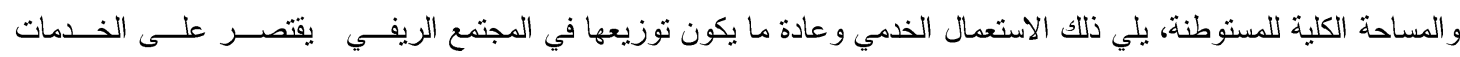

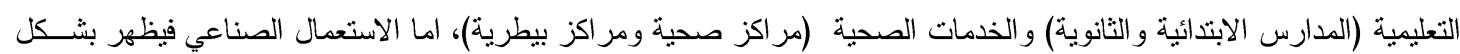

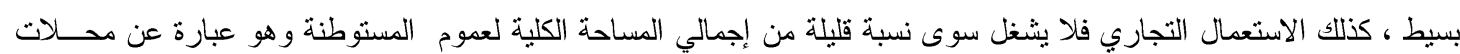

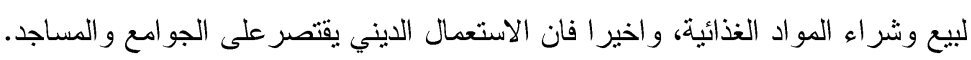

311] -2-3 -3 مورفولوجية المسكن الريفي

ان المسكن الريفي يختلف في نمطه ومو اد بنائه فمنه البسيط المتو اضع ومنه المخطط وبعضها ذات طابق و احد ومنهـــا ذات طابقين ومنها مابني من طين ولبن واخر من طابوق او حجر او قصب او بردي. تمثل اشكال وصور بناء المسكن الريفي تمثن بلا

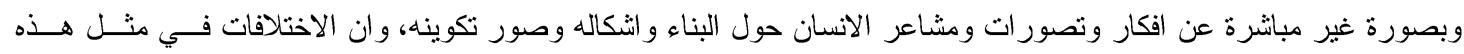

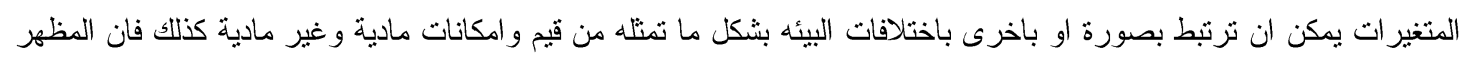

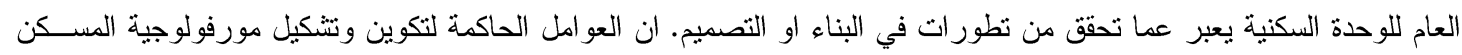

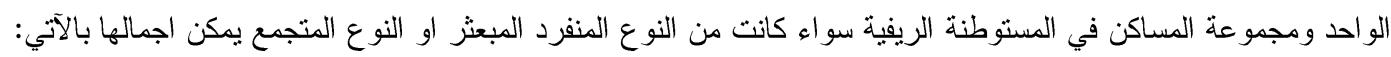

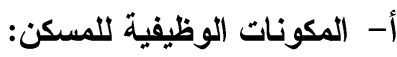

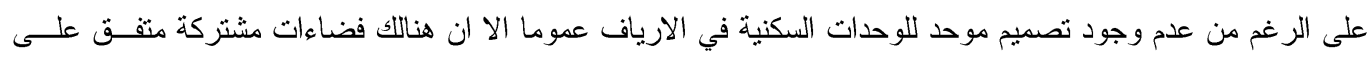

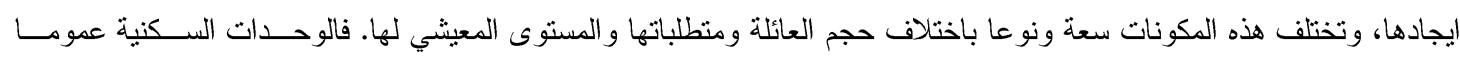

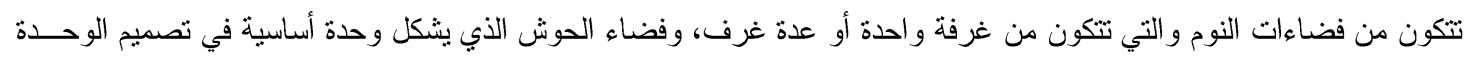

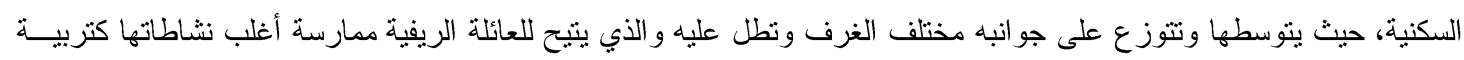

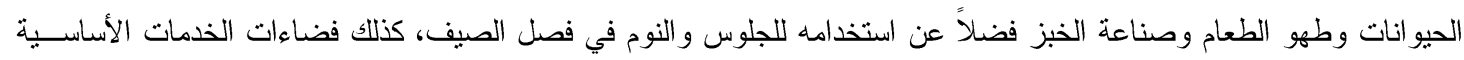

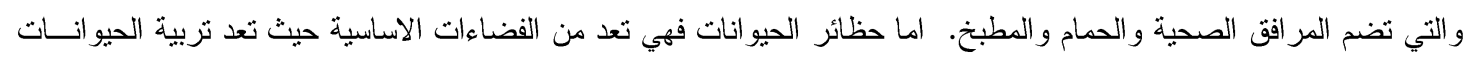

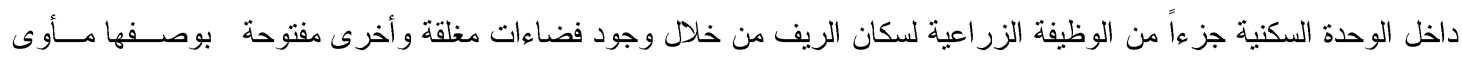

\section{ب- تصميم المسكن الريفي:}

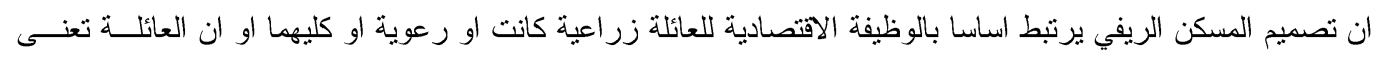

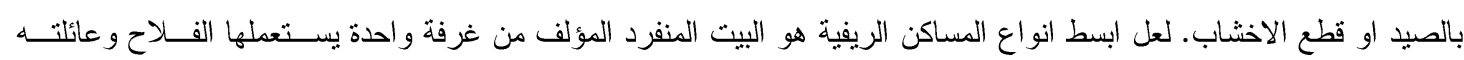

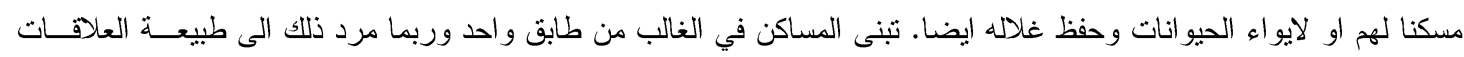

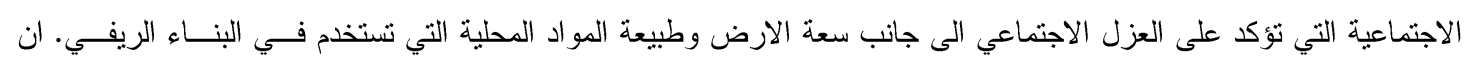
للمناخ دورا مهما في تصميم شكل المسكن الريفي لذا يلاحظ وجود ميل في السقوف في المناطق الممطرة، اما في الإِـاليم الحسـارة

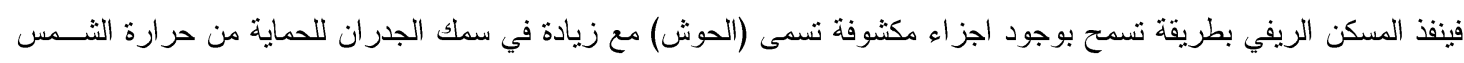

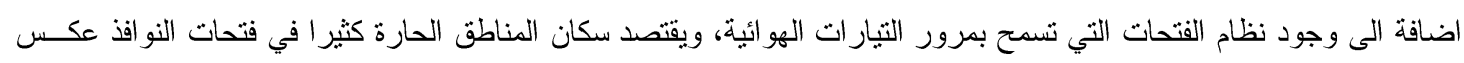

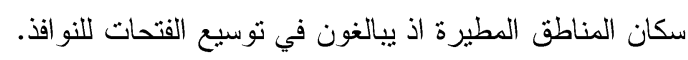

ج- نسيج البناء المعماري: 
ويقصد به مواد البناء الداخلة في هيكلها التصميمي و عدد الطوابق وطراز البناء وكالاتي:

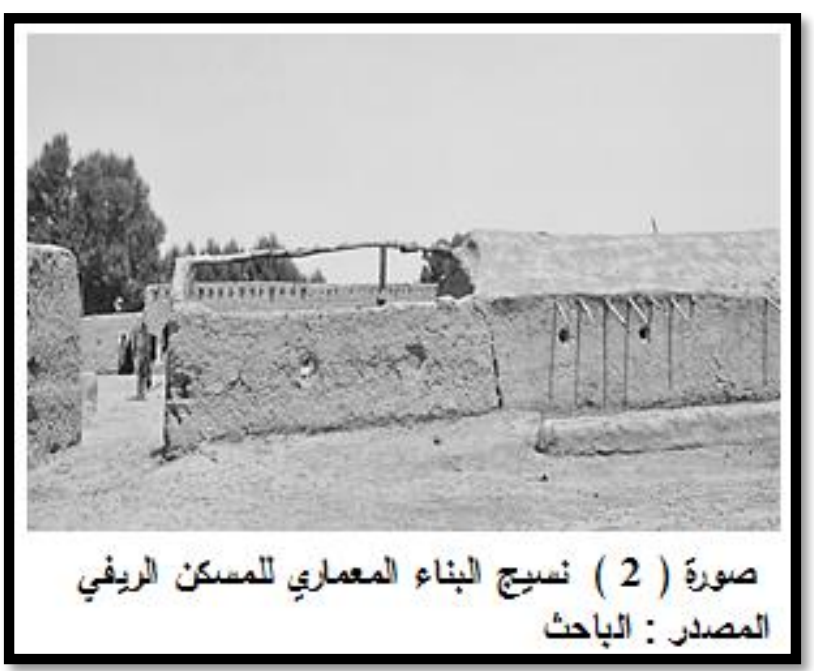

اولامواد البناء : تمثل مادة بناء الوحدة السكنية أمراً

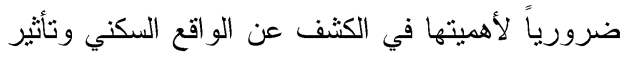

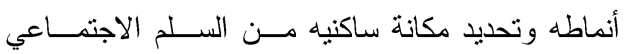

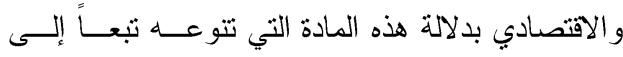

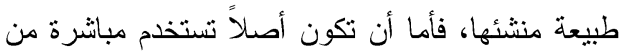
الأرض و التي تختلف حسب الموقع الجغر افي، وهذا ما

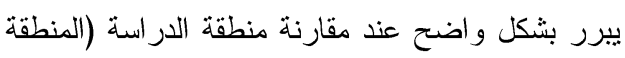

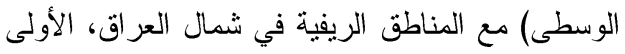

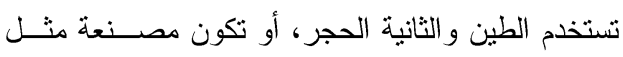
الطابوق و البلوك و الأسمنت و الجص التي أخذت تنتشــر في معظم أرجاء منطقة الدر اسة وما تعكسه من مسنوى

نوعي لصلاحية وكفاءة الوحدة السكنية. صورة (2)

ثانيا-عدد الطوابق : يعتمد في بناء المسكن الثخصي (بطابق أو طابقين) في أية مستوطنة على الوضع الاقتصادي للعائلـــة الــذي

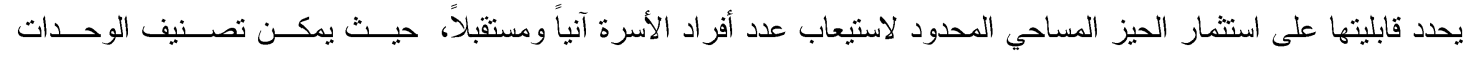

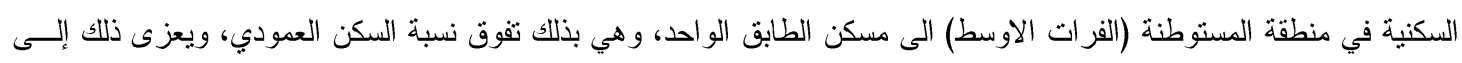

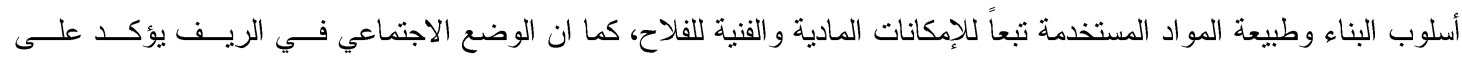

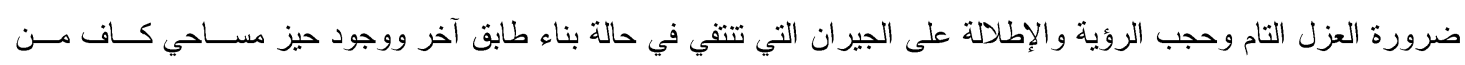
الأراضي بساعد على البناء الأفقي فضلاً عن أن مادة البناء بالطين تحول دون الامتداد العمودي.اما المسكن بطابقين فيمثل منظوراً

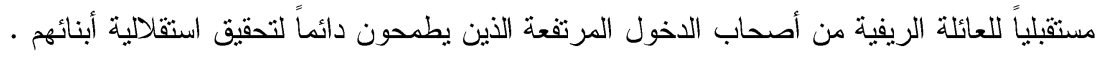

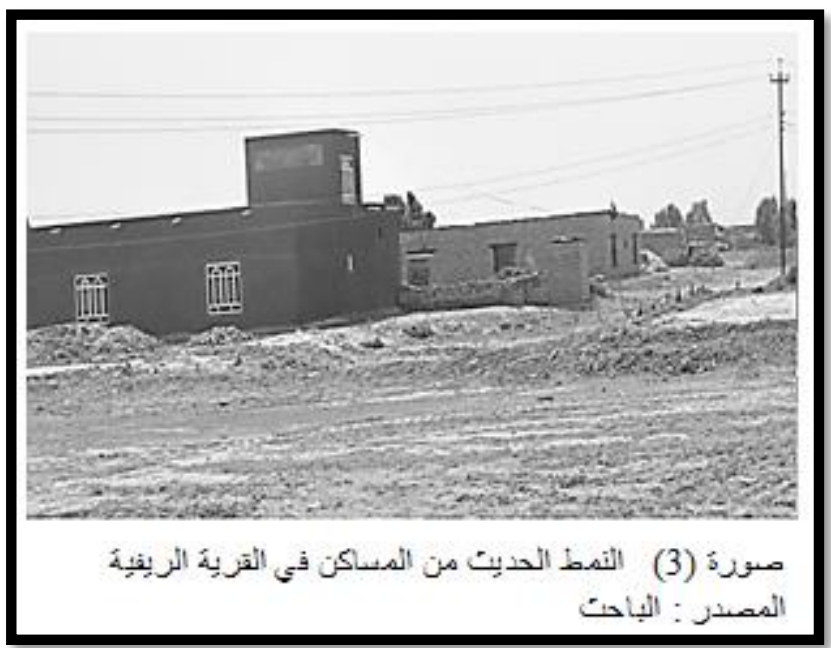

ثالثا-طراز البناء: إن طراز البناء للمسكن يعبر في

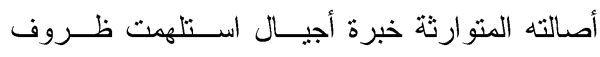
الريف الاجتماعية و الاقتصادية و المؤثرات الطبيعيــة اجنة لكون أهميته ليست حماية الإنسان من الظروف البيئية

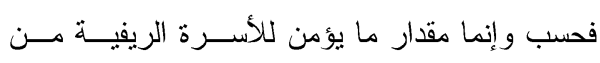

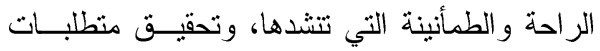
الحياة، لذا يمكن تمبيز نمطين من الوحدات الســكنية

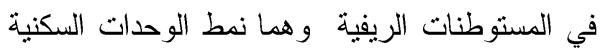

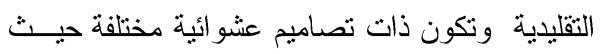

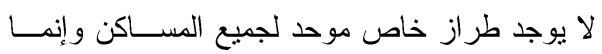

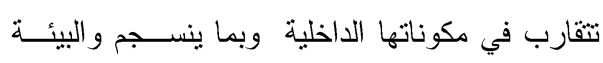

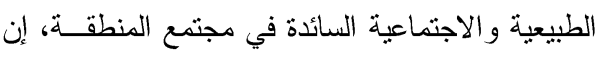

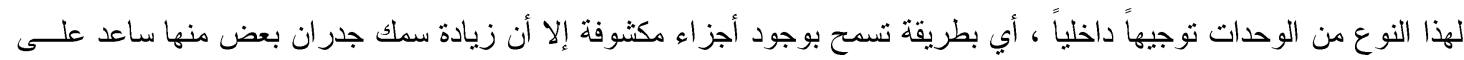

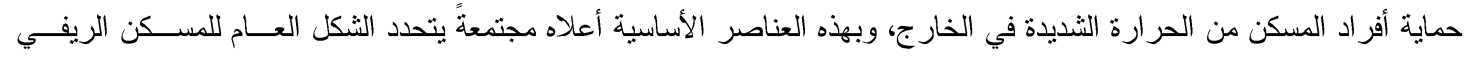

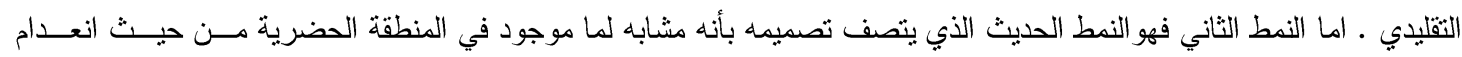

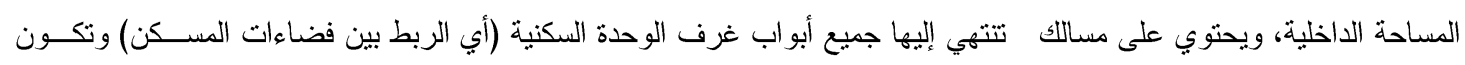

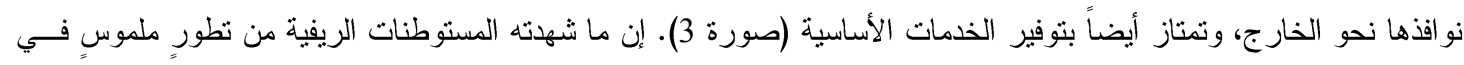

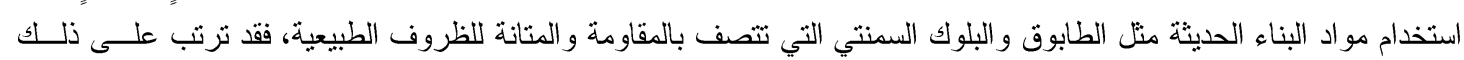

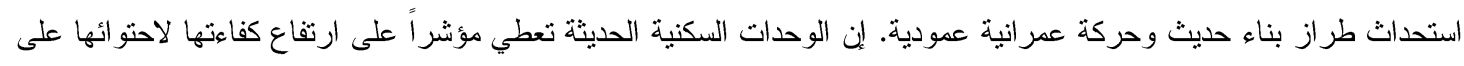


الفضاءات الخمية وما تمتاز به من إنارة وتهوية جيدة بما تمتلكه من نو افذو أبو اب ذات أبعاد نظامية خلافاً للوحدات المبنيــة مــن

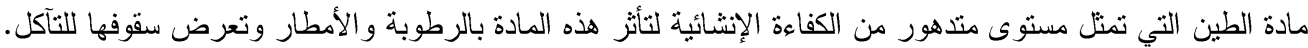

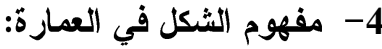

ان المبنى بصورة عامة يتألف من عدة منظومات منها منظومة الهيكل ومنظومة والخدمات وكذللك منظومة الثنكل الخارجي

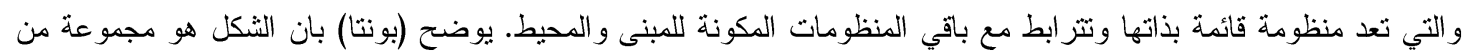

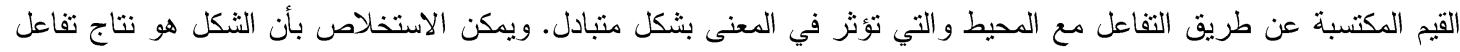

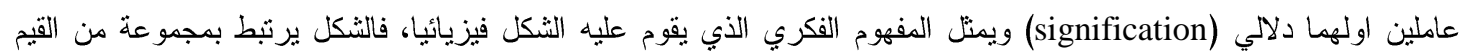

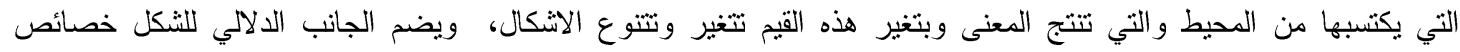

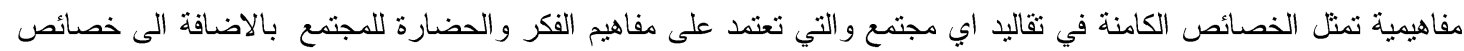

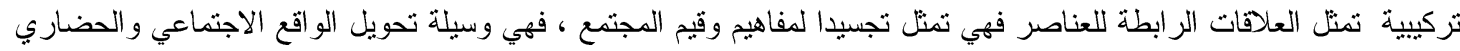

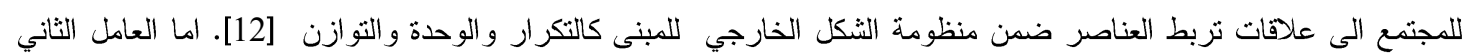
فهو مادي (material) ويمثل الجانب الفيزيائي المادي المدرك من الثنكل و هو يرتبط بالخصائص المظهرية الني يمكن استثمارها في تكوين الثنكل الخارجي كالهيئة و الحجم و اللون و الملمس.

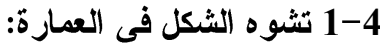

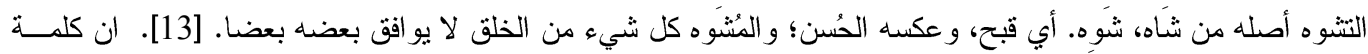

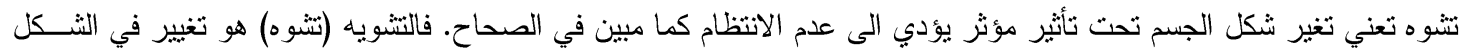

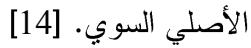

يستخدم مصطلح التثوه غالبا للتعبير عن الثنيء المغاير للطبع و الذوق و المخالف للغرض نتيجة لظلل يبعده عـن صــورته

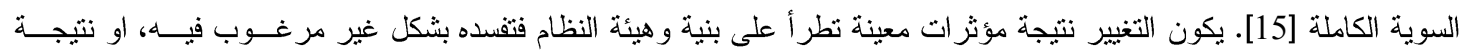

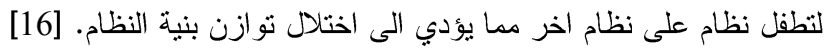

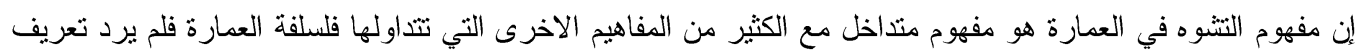

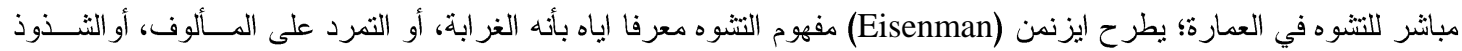

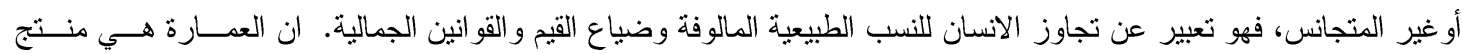

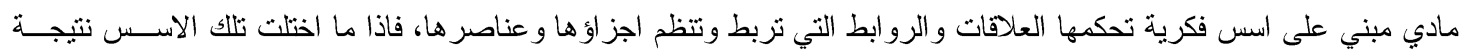

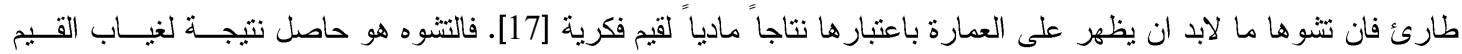

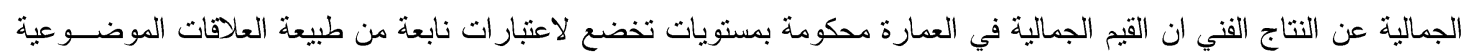

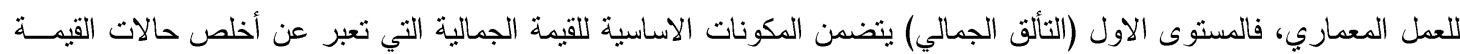

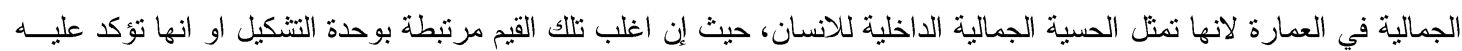

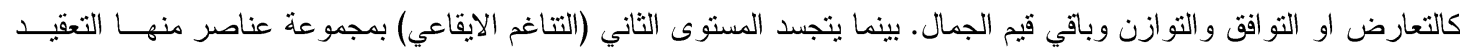

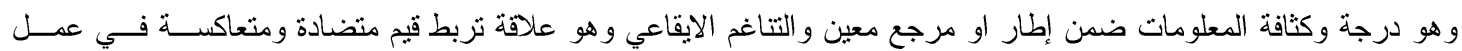

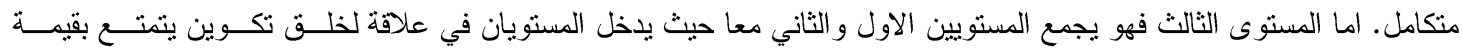

جمالية عالية [18]

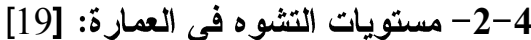

أ-المستوى الاول: تثتوه البنية القيمية الدلالية للاثكال، يستهدف هذا التثتوه البنية القيمية الدالالية للاثكال بما تضم تلك البنيــة مـن

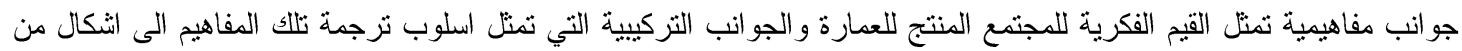
خلال خلق العلاقات التي تتظم العناصر المادية وهي تثمل قيم موضوعية كالاتز ان والوحدة و التتاسق. 
ب-المستوى الثاني: تثويش الرسالة و المعاني، ويرتبط بالجوانب المادية الملموسة للثكل التي تعبر عن الفكر وفي حالة قطعها عن

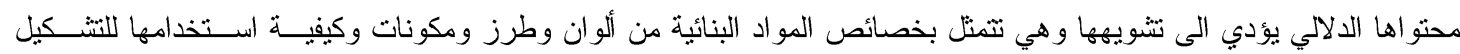
و التعبير

ث-المستوى الثالث: تثوه الاشكال المادية والفيزيائية، ويرتبط هذا المستوى بالجوانب المادية الملموسة للثكل والتي هي تعبير عن

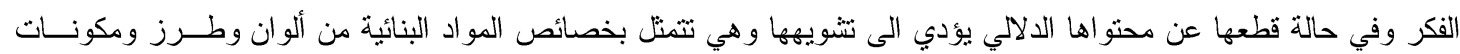
وكيفية استخدامها للنشكيل و التعبير.

جدول (1) مستويات تثوه الاشكال، المصدر: [19]

\begin{tabular}{|c|c|c|}
\hline المفردة الثانوية & المفردة الرئيسية & مستوى التشوه \\
\hline الوحدة & \multirow{6}{*}{ الصفات التركييية } & \multirow{6}{*}{ التشوه في بنية } \\
\hline التكر ار & & \\
\hline الاتزان & & \\
\hline التتاسق & & \\
\hline التو افق & & \\
\hline التتاظر & & \\
\hline 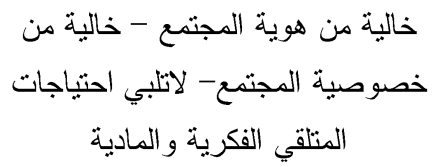 & العناصر التشكيلية & تشويش الرسالة \\
\hline اللون - الاشكال - الملمس- الطر از & البساطة الب المادية & التثوه البصري \\
\hline
\end{tabular}

5- الجاتب التطبيقي: لغرض اثبات معطيات الجانب النظري من البحث وبيان مصداقية الفرضية، فقد تم دراسة مجموعة قرى تقع

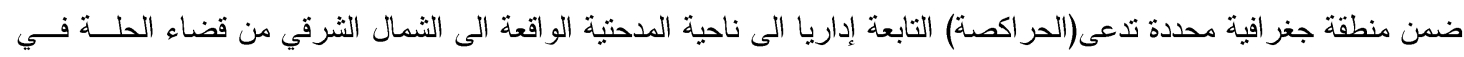
محافظة بابل والتي تمثل و اقع الريف العر اقي في المنطقة الوسطى، كما موضح في الثنكل رقم (1).

\section{5- 1 - وصف منطقة (لار اسة:}

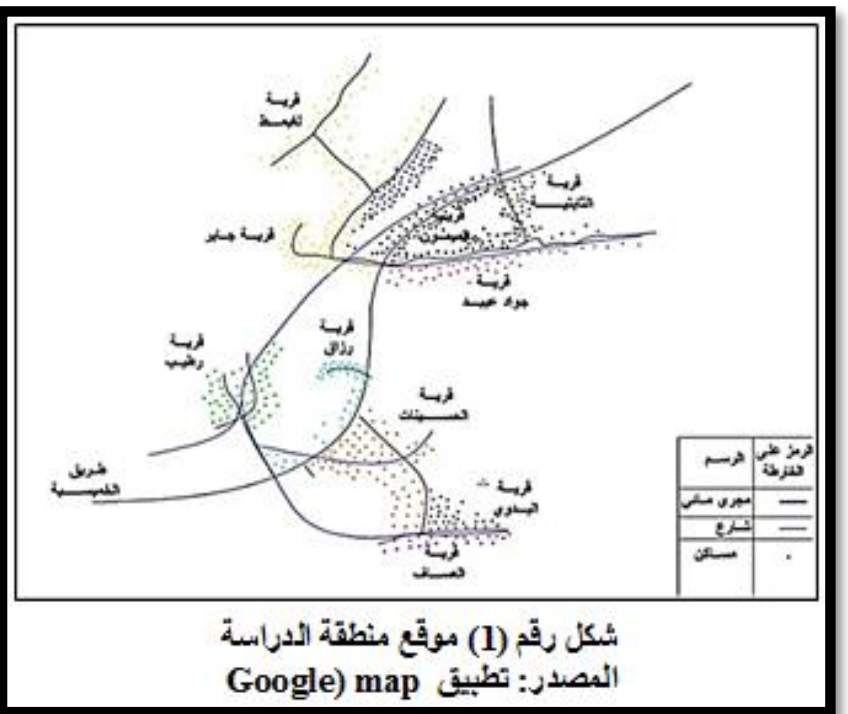

إن منطقة الدر اســة تثكــون مــن عثــر

مستوطنات ريفية متفاونة الحجم، جميع سكان هـــه أنه المستوطنات هم من أبناء عثيرة واحــدة (عثــيرة الحر اكصة). وكما موضح في الثكل رقــم (1). إن أن

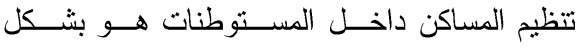
عشو ائي غير منتظم تاركة بينها ممــر ات تضـــيق

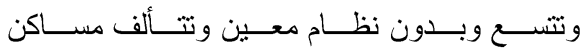

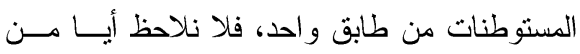

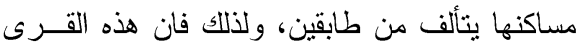

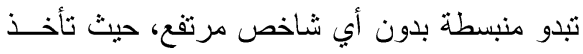
شكلا مستويا. و الجدول (2) يتضمن احصـائيات عدد السكان لكل قرية في منطقة الدر اســـة [20] - 
جدول (2): احصائيات وبيانات عن المستوطنات الريفية في منطقة الاراسة [20] - [21]

\begin{tabular}{|c|c|c|c|c|}
\hline عدد المساكن & مساحة الارض (دونم) & عدد الأفراد & اسم القرية & 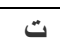 \\
\hline 480 & 5000 & 3000 & الميمون & -1 \\
\hline 380 & 3000 & 2000 & الحسينات & -2 \\
\hline 230 & 1500 & 1000 & البديوي & -3 \\
\hline 270 & 1500 & 1000 & العساف & -4 \\
\hline 300 & 6000 & 2000 & لغيمط & -5 \\
\hline 280 & 2000 & 1500 & رطيب & -6 \\
\hline 250 & 6000 & 300 & رزاق شربو & -7 \\
\hline 200 & 800 & 270 & تركي جابر & -8 \\
\hline 260 & 2000 & 1000 & الثابتية & -9 \\
\hline 225 & 800 & 450 & جواد عبيد & -10 \\
\hline
\end{tabular}

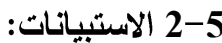

تضمن الجانب النطبيقي جانيين، الاول تضمن اجراء استيبان لمعرفة اراء السكان في المستوطنات الريفية المنتخبة

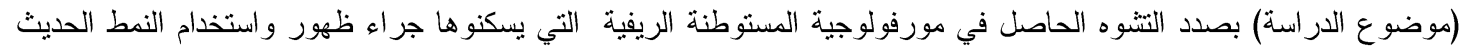
من الابنية السكنية ووجودها جنبا الى جنب مع المساكن الريفية التقليدية، حيث تم التزكيز على التثوه الحاصل نتيجة (تنويش

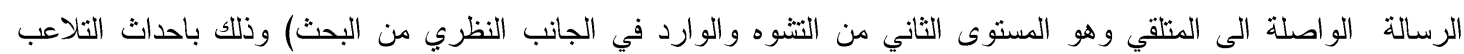
و الخلط بالعناصر التثكيلية للمبنى والذي يقود بالنتيجة الى فقدان هوية وخصوصية المجتمع وعدم امكانية تلبية احتباجات المتلقي

الفكرية و المادية وكما هو موضح في الجدول ( 3 ).

\section{جلول (3) اسئلة الاستبيان الخاص بسكان المستوطنات الريفية موضوع الدراسة}

\begin{tabular}{|c|c|c|c|}
\hline حديث & تقليدي & الاسئلة & $ت$ \\
\hline & & هل التعديلات التي تجريها على مسكنك مشابهة لنمط البيت التقليدي ام الحديث ؟ & 1 \\
\hline & & هل يوفر النمط الحديث من البناء الراحة ام النمط التقليدي ؟ & 2 \\
\hline & & ايهما اجمل مظهر ا بر ايكك ، المنزل التقليدي ام الحديث ؟ & 3 \\
\hline & & هل تفكر في تعديل مسكنك التقليدي الى نمط بناء حديث ؟ & 4 \\
\hline & & هل المسكن الحديث ملائم لمتطلبات مهنتاك ام التقليدي ؟ & 5 \\
\hline & & هل يوفر المسكن التقليدي العزلة والخصوصية للك ام المسكن الحديث؟ & 6 \\
\hline
\end{tabular}

لقد تم انتخاب عينات من سكنة مجموعة القرى المذكورة سابقا (منطقة الدراسة) وبعدد 30 ساكن ونم الاستفسار عن

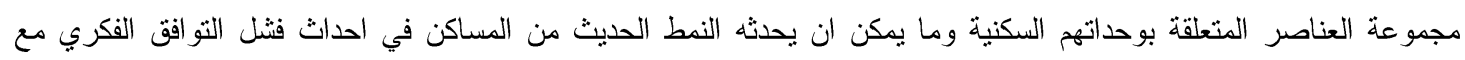

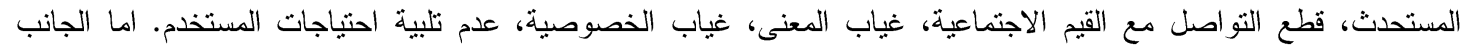

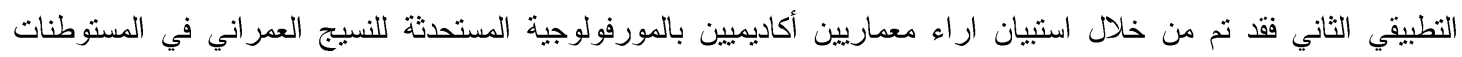
الريفية (موضوع الدراسة) من خلال تأكيد او نفي حصول التثوه في مورفولوجية المستوطنة الريفية نتيجة ظهور النمط الحيث التيث

واختلاطه بالنمط النقليدي من المساكن الريفية.

ومن اجل قياس و اثنات حصول حالة التثوه المورفولوجي في النسيج السكني الزيفي المتضمن للنمط الحديث فقد تم القياس

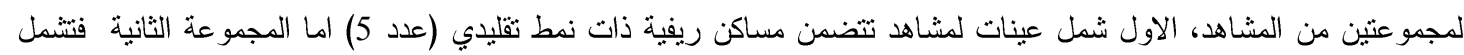

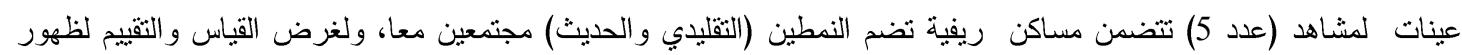

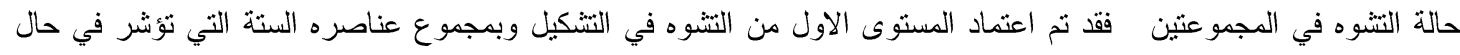

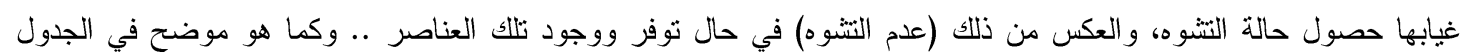


لقد نم القياس و التقييم من قبل مجموعة (عدد 10) معماريين أكاديميين وبموجب نموذج الاستييان (2) الوارد في المرفق 2 من البحث، لييان وجود او غياب عناصر جمال التتكيل الستة وكما هو مستخلص من الجانب النظري من البحث، حيث ثم

القياس باحتساب نقطة واحدة في حالة تقييم وجود العنصر يقابلها القيمة (صفر) في حالة غياب العنصر ، الجدول (4)

جدول (4) اسئلة الاستبيان الخاص بالخبر اء المعماريين

\begin{tabular}{|c|c|c|c|c|c|}
\hline غير موجود & موجود & خصائص الثكل & $ت$ & \multicolumn{2}{|c|}{ مستوى التشوه الاول } \\
\hline & & الوحدة & 1 & \multirow{6}{*}{ التركيبية } & \multirow{6}{*}{ التشوه في بنية } \\
\hline & & التكر ار & 2 & & \\
\hline & & الاتز ان & 3 & & \\
\hline & & التتاسق & 4 & & \\
\hline & & التو افق & 5 & & \\
\hline & & التناظر & 6 & & \\
\hline
\end{tabular}

5-3-3 التحليل و النتائج (استبيان 1):

خلصت نتائج الاستبيان رقم (1) لساكني المنازل في المستوطنات القروية (الوارد في المرفق 1) الــى تفضــيل واضـح احصائيا للنموذج التقليدي من المساكن من قبل الساكنين وعدم التقبل احصائيا لنموذج النمط الحديث من المساكن وحســب النتــائج الاتية و الممنلة بنسب مئوية:

تفضيل الساكنين اجر اء التعديلات او التوسعة ضمن مسكنهم التقليدي الى النمط التقليدي وكانت نسبة التفضيل (67\% نمـــ

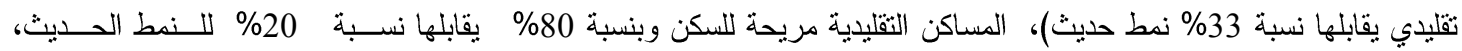

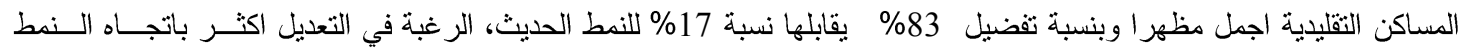
التقليدي وبنسبة تفضيل \%7\% يقابلها نسبة 33\%، المساكن التقليدية ملائمة لمنطلبات مهنة الساكنين وبنسبة تفضيل 70\% بقابلها نسبة 30\% نمط حديث، المساكن التقليدية نوفر الخصوصبة للساكنين وبنسبة تفضيل 83\% يقابلها نسبة 17\% نمط حديث. مما تقدم من معطيات يتيين ملاعمة النمط التقليدي لطبيعة الحياة و السلوك الاجتماعي للساكنين ضمن المستوطنة الريفية، مما

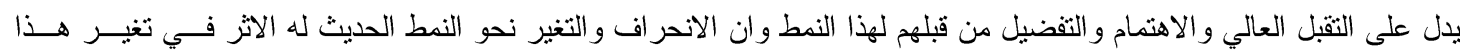
التقبل ابتداءأ من الصورة والمورفولوجية الغريبة التي يظهر ها النمط الحديث و عدم تجانسه مع ما قد اعتادوا عليه.

\section{5-4 التحليل والنتائج (استبيان 2):}

بينت نتائج الاستيان لمجموعة الخبر اء وبموجب نموذج الاستيبان رقم (2) لاحقا النتائج المبينة في الجـدول (5) وحسـب التفاصبل الاتية:

وجود خصائص الوحدة في مساكن النمط التقلبدي بنسبة (80\%) يقابله (20\%) لنماذج النمط المخــلط، وجــود عنصــر

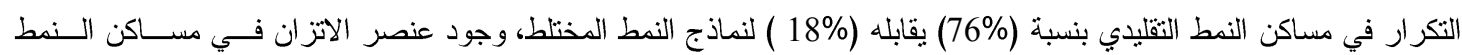
التقليدي بنسبة (68\%) يقابله (22\%) لنماذج النمط المختلط، وجود عنصر التتاسق في مساكن الــنمط التقليــدي بنسـبة (70\%) يقابله (18\%) لنماذج النمط المختلط، وجود عنصر التوافق في مساكن النمط التقليدي بنسبة (74\%) يقابله (24\%) لنماذج الــمط المختلط، وجود عنصر النتاظر في مساكن النمط التقليدي بنسبة (72\%) يقابله (18\%) لنماذج النمط المختلط. 
نماذج مثاهد مساكن ذات النمط التقليدي (استبيان 2)

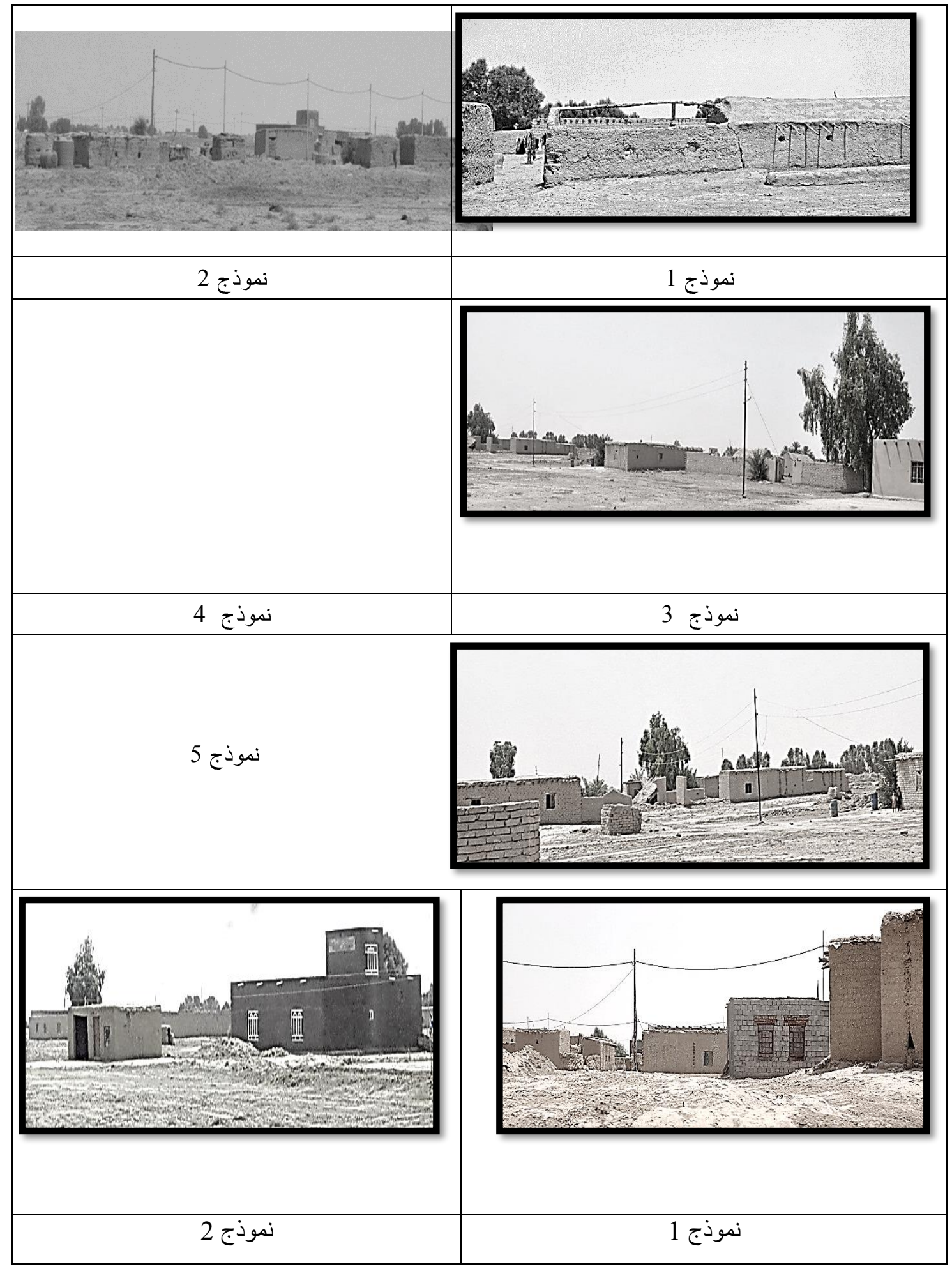




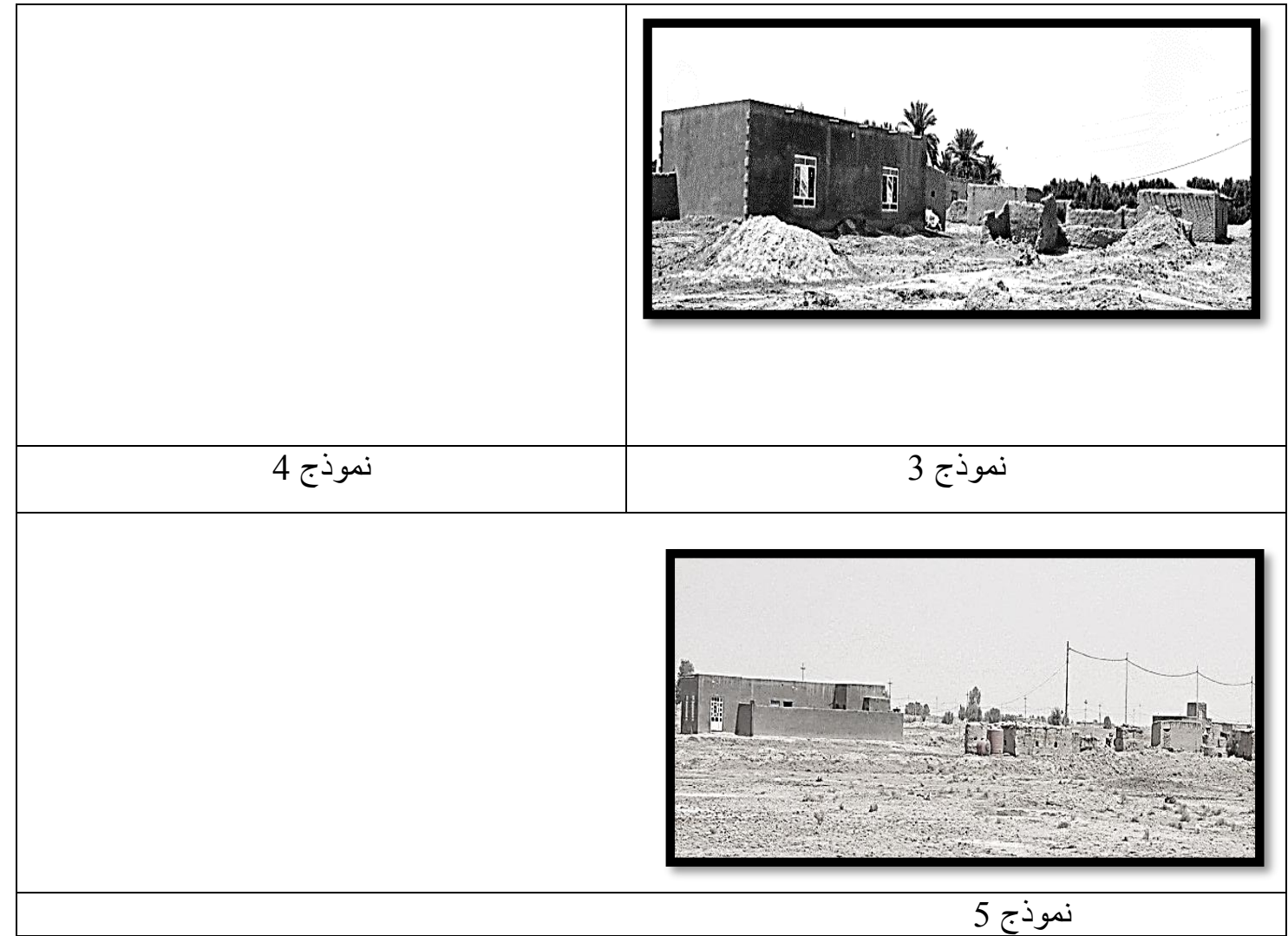

نماذج مشاهد مساكن مختلطة الأماط (استبيان 2)

مما تقدم من معطيات يتثين وجود عناصر جمال التثكيل الستة في نماذج النمط التقلبدي من المساكن الريفية بمسـتويات

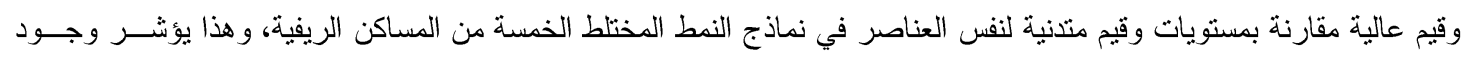
وظهور التثوه في البنية الثكلية للمساكن الريفية التي تظهر فيها الانماط الحديثة من المساكن مقارنة بسلامة وجمال البنية الثنــكلية

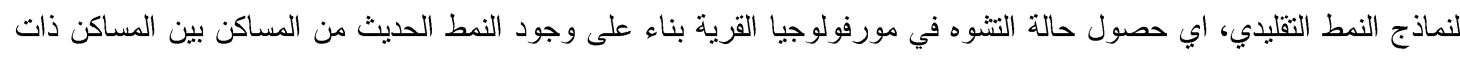
النمط النقليدي وهو ما يؤيد فرضية البحث.

جدول (5) نتائج استبيان مجموعة الخبراء المعماريين

\begin{tabular}{|c|c|c|c|c|c|c|c|c|c|c|c|c|c|c|c|}
\hline & & \multicolumn{5}{|c|}{ النمط المختلط } & & & \multicolumn{5}{|c|}{ النمط التقليدي } & \multirow[b]{2}{*}{ خصائ } & \\
\hline النسبة & المجموع & ص & ص & ص 3 & & ص 1 & النسبة & المجموع & ص 5 & ص ص 4 & ص 3 & & ص 1 & & \\
\hline$\% 20$ & 10 & 2 & 1 & 1 & 3 & 3 & $\% 80$ & 40 & 7 & 9 & 7 & 8 & 9 & الوحدة & \\
\hline$\% 18$ & 9 & 1 & 2 & 1 & 1 & 4 & $\% 76$ & 38 & 6 & 9 & 8 & 7 & 8 & التنكرار & \multirow{5}{*}{ الثي بنثة } \\
\hline$\% 22$ & 11 & 2 & 3 & 2 & 1 & 3 & $\% 68$ & 34 & 6 & 8 & 7 & 6 & 7 & الاتزان & \\
\hline$\% 18$ & 9 & 2 & 1 & 3 & 2 & 1 & $\% 70$ & 35 & 8 & 6 & 7 & 6 & 8 & التناسق & \\
\hline$\% 24$ & 12 & 2 & 3 & 2 & 1 & 4 & $\% 74$ & 37 & 7 & 9 & 7 & 8 & 6 & التو (فق & \\
\hline$\% 18$ & 9 & 1 & 2 & 1 & 2 & 3 & $\% 72$ & 36 & 9 & 6 & 7 & 6 & 8 & التناظر & \\
\hline
\end{tabular}




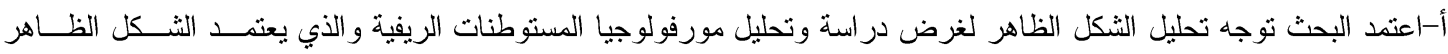
للمسنوطنة وشكل النسيج العمر اني ضمنها، ولقد تم الاقتصـار على در اسة وتحليل شكل النسيج السكني حصر ا حيث يمثل غالييـة الابنية الموجودة ضمن المستوطنة

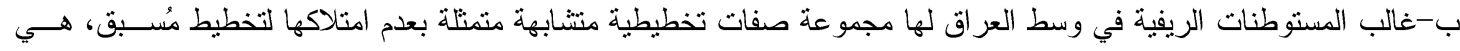
تتمثل بعدة أثنكال وذللك حسب طبيعة الموقع الذي نشأت عليه تلك المستوطنة كما ان مُعظم طرق هذه المســتوطنات ومســالكها

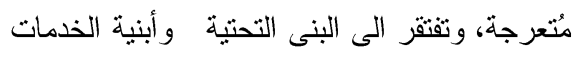

ت تم حصر العناصر المكونة لمورفولوجية المستوطنة الريفية بالآتي: أنظمة الثوارع، نمط قطـــع الأراضــي، أنمــاط الأبنيــة،

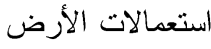

ث- مورفولوجية المسكن الريفي تمثل أحد العناصر الاساسية المكونة لمرفولوجيا المستوطنة الريفية والتي تمتلك العناصــر الاتيــة (المكونات الوظيفية، اسلوب التصميم، نسيج البناء المعماري المتمثل بمواد البناء، عدد الطوابق وطر از البناء)

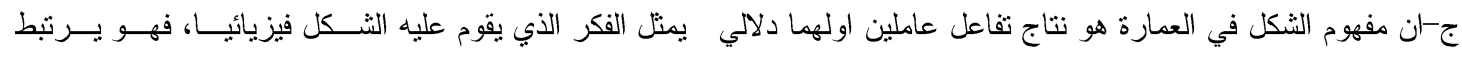

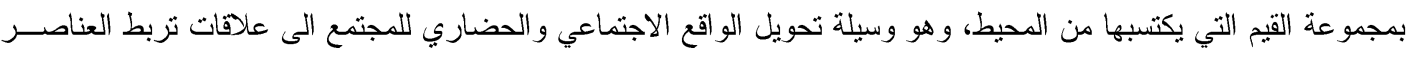

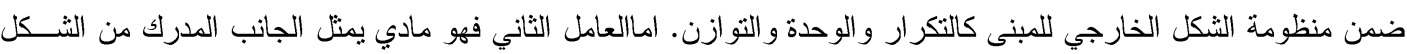
و هو يرتبط بالخصائص المظهرية التي يمكن استثمار ها في تكوين الثنكل الخارجي كالهيئة والحجم و اللون و الملمس.

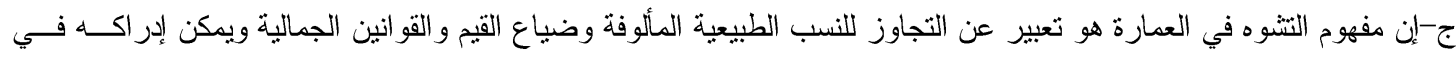

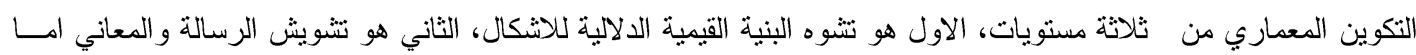
الثالث فهو تثوه الاشكال المادي و الفيزيائي حكباعتماد فحص التشوه في التتكيل العمر اني للنسيج السكني في المستوين الاول و الثاني (نطاق وحدود البحث) ومــاير افق هـذذين

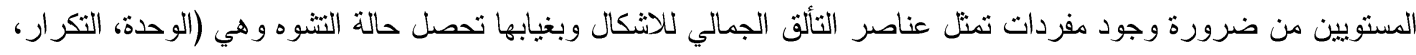

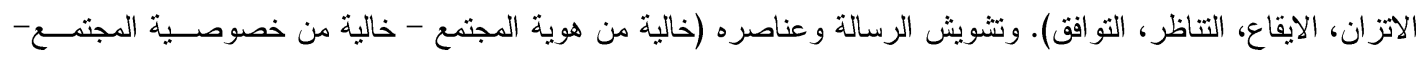
لاتلبي احتياجات المثلقي الفكرية و المادية)

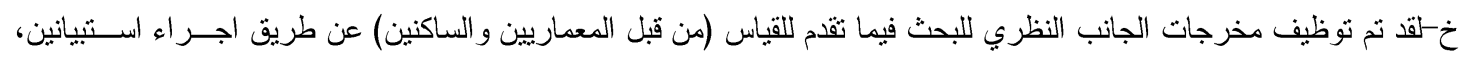
الاول استيبان ار اء اصحاب المساكن ومدى تقبلهم للمساكن التقليدية و المساكن الحديثة الطر از بينما شمل استبيان اخر مجموعـة فئة من الخبر اء المعماريين لقياس وفرة او غياب العناصر الجمالية للتشكيل ابي حصول حالة التثوه من عدمه (المستوى الاول) فـي وني نماذج من الصور للمجموعتين (النماذج التقليدية يقابلها النماذج المختلطة).

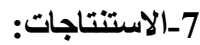

مما تقدم من معطيات ظهرت الاستتناجات الاتية:

أ-ملاعمة النمط التقليدي لطبيعة الحياة و السلوك الاجتماعي للساكنين ضمن المستوطنة الريفية، والتقبل العالي والاهنمام والتفضـيل من قبلهم لهذا النمط

ب-إن الانحر اف والتغير نحو النمط الحديث له الاثر في تغير هذا التقبل ابتداءأ من الصورة والمورفولوجية الغريبة التي يظهرهــا النمط الحديث و عدم تجانسه مع مع ما قد اعتادو الحزئ عليه.

ت-امكانية تمييز عناصر جمال النتكيل في نماذج المساكن ذات النمط التقليدي في المستوطنة الريفية بمستويات وقيم عالية مقارنــة بمستويات وقيم مندنية في نماذج النمط المختلط من المساكن الريفية،

ثـوجود وظهور التشوه في البنية الثكلية للمساكن الريفية التي تظهر فيها الانماط الحديثة من المساكن مقارنــة بسـلامة وجمــال البنية الثنلية لنماذج النمط التقليدي، اي حصول حالة التتوه في مورفولوجيا القرية بناء على وجود النمط الحديث من المســاكن بين المساكن ذات النمط التقليدي.

CONFLICT OF INTERESTS.

- There are no conflicts of interest. 


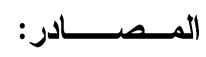

[1] عمر ، احمد مختار، معجم اللفة العربية المعاصر، المجلد الاول، الطبعة الاولى، القاهرة 2008.

[2] الديوجي، ممتاز حازم، أثر التغيرات المورفولوجية في النسيج الحضري على خصائصه التركيبية، قسم الهندسـة المعماريـة،

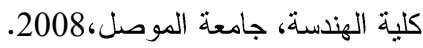

[3] Schulz: Norberg Christian, Existence Space \& Architecture, N.Y., 1971.

[4]Steadman J.P, Architecture morphology, Pion Press, 1983

[5] Carter: Harold, the Study of Urban Geography, London, 3rd, 1986

[6] العباسي، زيد محمد قدوري "أثر المعالم الدينية في مورفولوجية مركز مدينة سامر اء" رسالة ماجستير، قسم هندسـة العمــارة، الجامعة التكنولوجية 2014.

[7] Jordy Guth, "A rural character planning tool: modeling components of settlement pattern", College of Natural Resources, Utah State University, 2009.

[8] صعب، عبد الرزاق احمد سعيد، المستقرات الريفية في العراق، مجلة دراسات تربوية، العدد الساد 2009

[9] عبد الجبار، فائز عبد الحميد "دراسة تحليلية لواقع السكن الريفي في القرى الطينية في وسط العراق" رسـالة ماجستير، قسم الهندسة المعمارية جامعه بغداد، حزير الئ سنة 1980.

[10] عبود، عادل عبدالامير، مورفولوجية المستوطنات الريفية في قضاء ابي الخصيب، شبكة البصرة الثقافية ، 2009

[11] الحلاوي، سماح ابر اهيم شمخي، مورفولوجية المسكن الريفي. كلية التربية الاساسية، شبكة جامعة بابل ، 2011

[12] عقيل، صـادق محمد، خصـائص تصميم الثكل الخـارجي للمسكن في العراق، رسـالة ماجستير، جامعة بغداد، كلية الهندسة ، 1996

[13] اليسو عي، لويس معلوف و المنجد في اللغة، المطبعة الكاثوليكيةز بيروت ، 1979

[14] العلايلي، العلامة الثيخ عبد الله، الصحاح في اللغة والعلوم، دار الحضارة العربية، بيروت 1975

1979، 15 اليسوعي، لويس معلوف، المنجد في اللغة، المطبعة الكاتوليكية، بيروت

[16] الجبوري، نسرين رزاق، التلوث البصري في البيئة الحضرية، رسالة ماجستير، جامعة بغداد، 2000

[17] العتابي، مهدي صلالح الفرج، الاصالة في العمارة المعاصرة، اطروحة دكتور اه، الجامعة التكنلوجية، 2006

[18] شكر، عصام علي، نظريات الجمال وتطبيقها على العمـارة العربية الاسـلامية، رسـالة ماجستير، جامعة بغداد، كلية الهندسة /

[19] علوان، علي عدنان، أثر الحراك الاجتماعي في تثوه واجهات الدور السكنية، المجلة المجلة العر اقيـة للهندسـة المعماريـة، العدد الاول، كانون الثاني 2017

2018 [20] دائرة احصاء بابل

2018 [21] مديرية ناحية المدحتية 


\section{(1) (1) - nenمارة الاستبيان}

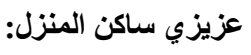

هذا نموذج استييان لغرض استكمال بحث متعلق بدراسة (الانماط الحديثة للوحدات السكنية و أثزرها في تنثويه مورفولوجيا

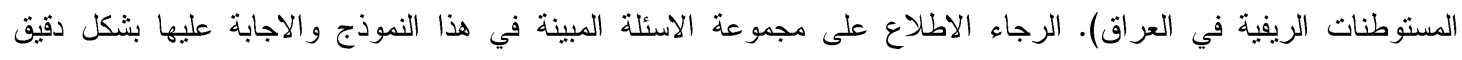

وموجز ---- شكرا لتعاونكم

\begin{tabular}{|c|c|c|c|}
\hline الحديث & التقليدي & & \\
\hline & & هل التعديلات التي تجريها على مسكنك مشابهة للبيت التقليدي ام الحديث ؟ & 1 \\
\hline & & هل يوفر النمط الحديث من البناء الراحة ام النمط التقليدي ؟ & 2 \\
\hline & & ايهما اجمل مظهر ابرايك ، المنزل التقليدي ام الحديث ؟ & 3 \\
\hline & & هل تفكر في تعديل مسكنك التقليدي الى نمط بناء حديث ؟ & 4 \\
\hline & & هل المسكن الديث ملائم لمنطلبات مهنتك ام التقليدي ؟ & 5 \\
\hline & & هل يوفر المسكن التقليدي الخصوصية لك ام الحديث & 6 \\
\hline
\end{tabular}

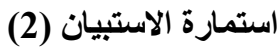

عزيزي الخبيز:

هذا نموذج استيان لغرض استكمال بحث منعلق بدراسة (الانماط الحديثة للوحدات السكنية و أثنرها في نتثويه مورفولوجيا

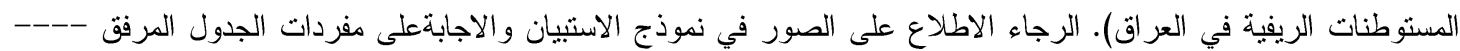
شكر ا لتعاونكم

\begin{tabular}{|c|c|c|c|c|}
\hline غير موجود & موجود & خصائص الثنكل & & مستوى التثوه \\
\hline & & الوحدة & 1 & \multirow{6}{*}{ التشوه في بنية } \\
\hline & & التكرار & 2 & \\
\hline & & الاتزان & 3 & \\
\hline & & التناسث & 4 & \\
\hline & & التو افق & 5 & \\
\hline & & التناظر & 6 & \\
\hline
\end{tabular}

